\title{
Article
}

\section{The Cytotoxic Activity of Diiron Bis-Cyclopentadienyl Complexes with Bridging $\mathrm{C}_{3}$-Ligands}

\author{
Simona Braccini $\left(D\right.$, Giacomo Provinciali ${ }^{\dagger}$, Lorenzo Biancalana $(D)$, Guido Pampaloni (D), Federica Chiellini $*, \ddagger(\mathbb{D}$ \\ and Fabio Marchetti *iD
}

Citation: Braccini, S.; Provinciali, G.; Biancalana, L.; Pampaloni, G.; Chiellini, F.; Marchetti, F. The Cytotoxic Activity of Diiron Bis-Cyclopentadienyl Complexes with Bridging $\mathrm{C}_{3}$-Ligands. Appl. Sci. 2021, 11, 4351. https://doi.org/ 10.3390/app11104351

Academic Editor: Magdalena Biesaga

Received: 18 April 2021

Accepted: 7 May 2021

Published: 11 May 2021

Publisher's Note: MDPI stays neutra with regard to jurisdictional claims in published maps and institutional affiliations.

Copyright: (c) 2021 by the authors. Licensee MDPI, Basel, Switzerland. This article is an open access article distributed under the terms and conditions of the Creative Commons Attribution (CC BY) license (https:// creativecommons.org/licenses/by/ $4.0 /)$.
Department of Chemistry and Industrial Chemistry, University of Pisa, Via Moruzzi 13, I-56124 Pisa, Italy; simona.braccini@phd.unipi.it (S.B.); giacomoprovinciali@gmail.com (G.P.); lorenzo.biancalana@unipi.it (L.B.); guido.pampaloni@unipi.it (G.P.)

* Correspondence: federica.chiellini@unipi.it (F.C.); fabio.marchetti1974@unipi.it (F.M.)

+ Present address: CNR-ICCOM, Via Madonna del Piano 10, I-50019 Sesto Fiorentino, Italy.

$\ddagger$ Deceased on 7 March 2021.

Abstract: Diiron bis-cyclopentadienyl bis-carbonyl cationic complexes with a bridging vinyliminium ligand, $\left[\mathrm{Fe}_{2} \mathrm{Cp}_{2}(\mathrm{CO})(\mu-\mathrm{CO})\left\{\mu-\eta^{1}: \eta^{3}-\mathrm{C}^{3}\left(\mathrm{R}^{\prime}\right) \mathrm{C}^{2} \mathrm{HC}^{1} \mathrm{NMe}\left(\mathrm{R}^{\prime \prime}\right)\right\}\right] \mathrm{CF}_{3} \mathrm{SO}_{3}\left(\mathrm{R}=\mathrm{Xyl}=2,6-\mathrm{C}_{6} \mathrm{H}_{3} \mathrm{Me}_{2}\right.$, $\mathrm{R}^{\prime}=\mathrm{Ph}, \mathrm{R}^{\prime \prime}=\mathrm{H}, \mathbf{2} \mathbf{a} ; \mathrm{R}=\mathrm{Xyl}, \mathrm{R}^{\prime}=\mathrm{R}^{\prime \prime}=\mathrm{Me}, \mathbf{2} \mathbf{b} ; \mathrm{R}=\mathrm{R}^{\prime}=\mathrm{Me}, \mathrm{R}^{\prime \prime}=\mathrm{H}, \mathbf{2} \mathbf{c} ; \mathrm{R}=\mathrm{Me}, \mathrm{R}^{\prime}=$ 2-naphthyl, $\left.\mathrm{R}^{\prime \prime}=\mathrm{H}, \mathbf{2 d} ; \mathrm{R}=\mathrm{Me}, \mathrm{R}^{\prime}=\mathrm{R}^{\prime \prime}=\mathrm{Ph}, \mathbf{2 e}\right)$, are easily available from commercial chemicals, robust in aqueous media and exert a variable in vitro cytotoxicity against cancer cell lines depending on the nature of the substituents on the vinyliminium ligand. The anticancer activity is, at least in part, associated to fragmentation reactions, leading to iron oxidation and active neutral and well-defined monoiron species. We report an innovative synthetic procedure for the preparation of $\mathbf{2} \mathbf{a}, \mathbf{c}, \mathbf{d}$, and a facile method to access the monoiron derivative of $2 a$, i.e., $\left[\mathrm{FeCp}(\mathrm{CO})\left\{\mathrm{C}^{1}(\mathrm{NMeXyl}) \mathrm{C}^{2} \mathrm{HC}^{3}(\mathrm{Ph}) \mathrm{C}(\mathrm{O})\right\}\right]$ (3a). According to $\mathrm{IC}_{50}$ analyses at different times of incubation of the complexes, 3a is significantly faster in inhibiting cell viability compared to its diiron precursor $2 \mathbf{a}$. The neutral complexes $\left[\mathrm{Fe}_{2} \mathrm{Cp}_{2}(\mathrm{CO})(\mu-\mathrm{CO})\left\{\mu-\mathrm{k}^{1} \mathrm{~N}: \mathrm{k}^{1} \mathrm{C}: \mathrm{k}^{1} \mathrm{C}-\mathrm{C}^{3}\left(\mathrm{R}^{\prime}\right) \mathrm{C}^{2}(\mathrm{Se}) \mathrm{C}^{1}\left(\mathrm{NMe}_{2}\right) \mathrm{C}^{4}\left(\mathrm{CO}_{2} \mathrm{Y}\right) \mathrm{C}^{5}\left(\mathrm{CO}_{2} \mathrm{Y}\right)\right\}\right]\left(\mathrm{R}^{\prime}=\mathrm{Y}=\mathrm{Me}, \mathbf{4}\right.$; $\left.\mathrm{R}^{\prime}=\mathrm{Pr}, \mathrm{Y}={ }^{\mathrm{t}} \mathrm{Bu}, 4 \mathrm{~b} ; \mathrm{R}^{\prime}=\mathrm{Y}=\mathrm{Et}, 4 \mathrm{c}\right)$ are obtained via the two-step modification of the vinyliminium moiety and comprise a bridging selenophene-decorated alkylidene ligand. The antiproliferative activity exhibited by 4a-c is moderate but comparable on the ovarian cancer cell line A2780 and the corresponding cisplatin resistant cell line, A2780cisR. Complexes 4a-c in aqueous solutions undergo progressive release of the alkylidene ligand as a functionalized selenophene, this process being slower in cell culture medium. Since the released selenophenes $\operatorname{SeC}^{1}\left\{\mathrm{C}(\mathrm{O}) \mathrm{R}^{\prime}\right\} \mathrm{C}^{2}\left(\mathrm{NMe}_{2}\right) \mathrm{C}^{3}\left(\mathrm{CO}_{2} \mathrm{Y}\right) \mathrm{C}^{4}\left(\mathrm{CO}_{2} \mathrm{Y}\right)$ $\left(\mathrm{R}^{\prime}=\mathrm{Y}=\mathrm{Me}, \mathbf{5} \mathbf{a} ; \mathrm{R}^{\prime}=\mathrm{Pr}, \mathrm{Y}={ }^{\mathrm{t}} \mathrm{Bu}, \mathbf{5 b}\right)$ are substantially not cytotoxic, it is presumable that the activity of $4 \mathrm{a}-\mathrm{c}$ is largely ascribable to the $\left\{\mathrm{Fe}_{2} \mathrm{Cp}_{2}(\mathrm{CO})_{2}\right\}$ scaffold.

Keywords: metal-based drugs; diiron complexes; cytotoxicity; alkylidene ligand; selenophenes

\section{Introduction}

There is a current great interest in developing new anticancer drugs based on transition metals [1-4], due to the peculiar properties provided by the presence of the metal center (e.g., redox activity and broad possibility of geometries, stereochemical configurations and kinetic behaviors) [5] and the opportunity to overcome the drawbacks associated to the use of platinum compounds currently employed in clinical treatments against several types of tumors (in particular, severe side effects and acquired resistance towards the drug) [6,7].

In this regard, iron is an appealing choice as a metal element, being easily available, implicated in diverse biological processes in the human body, essentially nontoxic in many forms and displaying a rich redox chemistry [8,9]. Monometallic iron complexes with one or two (ferrocenes) cyclopentadienyl ligands $\left(\eta^{5}-\mathrm{C}_{5} \mathrm{H}_{5}=\mathrm{Cp}\right)$ have been widely investigated for their cytotoxicity [10-12], however these species may suffer from a limited 
structural variability and the absence of water solubility $[13,14]$, which is a highly desirable characteristic for a drug candidate.

Some of us have been involved for longtime in the organometallic chemistry of diiron bis-cyclopentadienyl complexes: with a notable relevance to the natural hydrogenase enzymes, the cooperative diiron core is a key feature, in that it enables reactivity patterns on the bridging site which are otherwise not accessible on homologous monoiron complexes, and thus leads to the stereo- and regio-selective stepwise construction of functionalized organic fragments $[15,16]$. The co-presence of $\mathrm{Cp}$ (electron donor) and CO (electron acceptor) ligands confers a substantial robustness to the complexes [17], and the fine control of the structural variability makes available a range of compounds with suitable physico-chemical properties for potential biological applications (e.g., appreciable water solubility, amphiphilicity).

We recently reported the first studies on the antiproliferative activity of di-organoiron complexes [18,19], and in particular we found that vinyliminium complexes $\mathbf{2}$ are substantially water-stable and exhibit a variable in vitro antiproliferative activity depending on the substituents on $N, C^{1}$ and $C^{2}$ [20-22]; 2 are usually prepared by means of a straightforward four-step procedure from the commercial $\left[\mathrm{Fe}_{2} \mathrm{Cp}_{2}(\mathrm{CO})_{4}\right]$, via the intermediacy of aminocarbyne complexes 1 (Scheme 1, path a) [20,23]. Remarkably, IC $_{50}$ values in the nanomolar range have been recognized on A2780 and A2780cisR cells for some complexes of the series 2. The action of 2 seems multimodal, including the interaction with biomolecules and the interference with cellular redox processes, and in particular the compounds possess the ability to trigger the production of Reactive Oxygen Species (ROS) inside the tumor cells [24-26]. In principle, two processes might contribute to this phenomenon: (1) a slow, extensive degradation of the diiron scaffold, with the released iron(I) centers rapidly converting into iron(III) oxide [20]; (2) a monoelectron reduction of the cationic complexes, promoting a fragmentation affording iron( 0 ) and the monoiron complexes 3 , which are themselves cytotoxic through the production of ROS and display a significant selectivity with reference to the noncancerous HEK-293 cell line [27]. The optimal laboratory preparation of 3 consists in the reaction of the precursors 2 with an amine (Scheme 1, path b). The neutral diiron complexes $4 \mathbf{a}-\mathrm{c}$ are accessible by means of a two-step synthesis consisting in the incorporation of a selenium atom within the vinyliminium moiety, followed by cyclization reaction with internal alkynes bearing electron withdrawing substituents (Scheme 1c) [28]. Complexes 4a-c are based on a $\left\{\mathrm{Fe}_{2} \mathrm{Cp}_{2}(\mathrm{CO})_{2}\right\}$ core and comprise an additional bridging ligand which is an alkylidene derivatized with an unusually functionalized selenophene. Complexes of type 4 slowly break up into their constituting pieces in aqueous solution in the presence of air, i.e., cyclopentadiene, carbon monoxide, the iron centers (converting into $\mathrm{Fe}^{\mathrm{III}}$ oxides) and the tetra-substituted selenophenes 5 (Scheme 1d) [29]. A very rare example of straightforward dissociation of a bridging Fischer alkylidene under mild conditions [30]. This approach has been proposed as a metal-assisted synthesis of organic molecules (5), otherwise not accessible following conventional routes. However, the expected, progressive release of the selenophene in physiological media, the related redox process involving the two irons and the fact that selenium may play some role against cancer [31-35], render 4 potentially intriguing from a biological perspective. Herein, we present an extension of our studies, including novel synthetic routes and the assessment of the cytotoxicity of various compounds under different conditions, with the primary aim of shedding light on the anticancer potential of diiron bis-cyclopentadienyl complexes and their mode of action. 


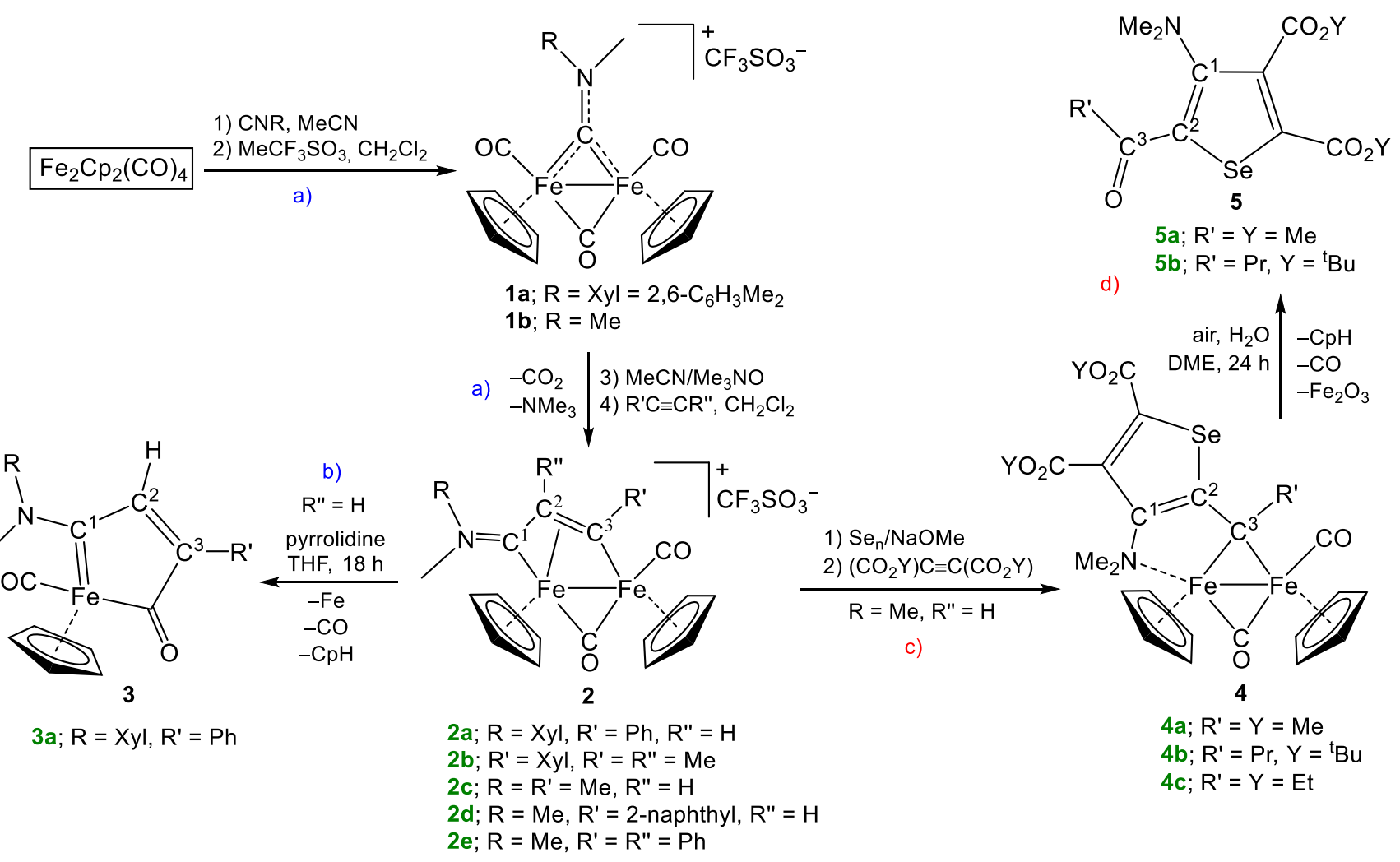

Scheme 1. (a) Four-step synthesis of diiron $\mu$-vinyliminium complexes $2\left(\mathrm{R}^{\prime}=\mathrm{H}\right.$, alkyl, aryl, $\mathrm{SiMe}_{3}, \mathrm{CO}_{2} \mathrm{Me}, \mathrm{N}-$ or $\mathrm{S}$ heterocycle; $\mathrm{R}^{\prime \prime}=\mathrm{H}$, alkyl or aryl); (b) reductive fragmentation to monoiron vinyl-aminoalkylidene 3; (c) synthesis of selenophene-decorated alkylidene complexes 4 ; (d) synthesis of tetrasubstituted selenophenes 5 via displacement of the alkylidene-selenophene ligand. Green: complexes investigated in the present work.

\section{Results and Discussion}

First, we developed a new and convenient method for the synthesis of the diiron vinyliminium complexes $\mathbf{2} \mathbf{a}, \mathbf{c}, \mathbf{d}$ from the parent aminocarbyne complexes $\mathbf{1 a} \mathbf{a} \mathbf{b}$ (Scheme 2, path a). The displacement of the carbonyl ligand by means of trimethylamine-N-oxide was carried out in methanol solution in the presence of the alkyne, and led to isolation of $\mathbf{2 a}, \mathbf{c}, \mathbf{d}$ in good to high yields, following alumina chromatography. Complexes $\mathbf{2} \mathbf{b}, \mathbf{e}$ were instead obtained according to the literature [20,36]. Using the improved synthetic procedure (Scheme 2), which is performed in one-pot without the needing of anhydrous solvents, the yields of $\mathbf{2 a}, \mathbf{c}, \mathbf{d}$ are similar to those obtained by means of the two-step synthesis [20,37].

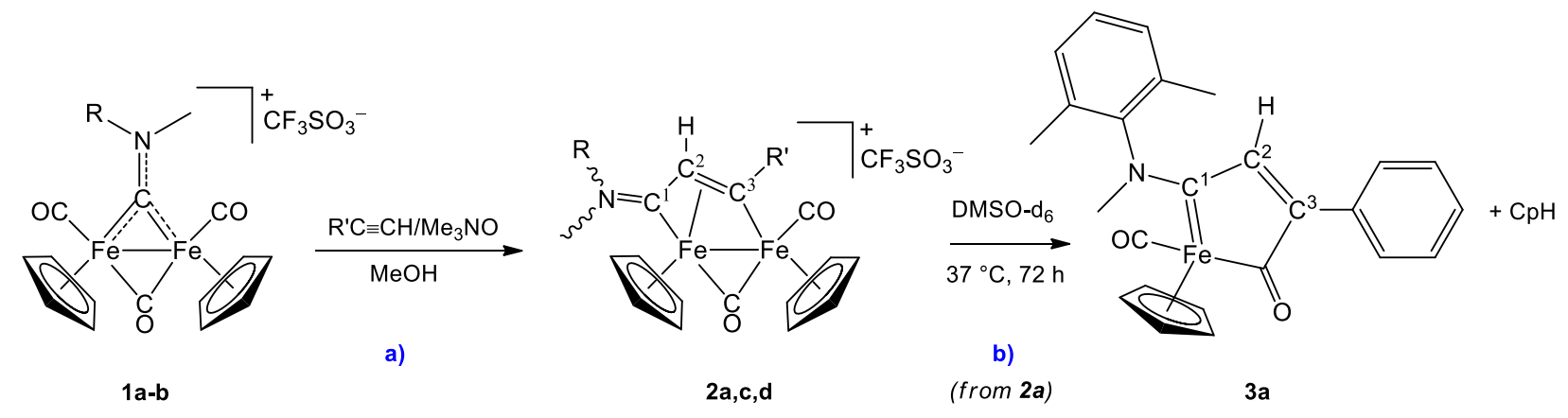

Scheme 2. (a) one-pot synthesis of diiron $\mu$-vinyliminium complexes from aminocarbyne precursors and terminal alkynes, and (b) DMSO-promoted conversion of $\mathbf{2}$ a into the monoiron vinyl-aminoalkylidene complex $\mathbf{3 a}$. 
Complexes $2 \mathbf{a}, \mathbf{c}, \mathbf{d}$ were unambiguously identified by means of their IR and ${ }^{1} \mathrm{H}$ NMR spectra (Figures S1-S3), being fully consistent with those reported previously (Figures S1-S3). The IR spectra of 2a-e (in $\mathrm{CH}_{2} \mathrm{Cl}_{2}$ ) share a common pattern with three bands, related to the terminal carbonyl ligand, the bridging carbonyl and the iminium function, respectively. For instance, in the case of 2c, such bands occur at 1990, 1806 and $1685 \mathrm{~cm}^{-1}$, in the order given. According to ${ }^{1} \mathrm{H}$ NMR spectroscopy, complex 2a exists as a 2:1 mixture of $\mathrm{E}$ and $\mathrm{Z}$ isomers related to the nitrogen substituents, due to hampered rotation around the $\mathrm{C}^{1}-\mathrm{N}$ axis, and both isomers share a common cis geometry of the $\mathrm{Cp}$ rings. The $\mathrm{E} / \mathrm{Z}$ isomeric ratio resembles that one recognized following the former procedure. On the other hand, the NMR spectra of $\mathbf{2 c}, \mathbf{d}$ display a single set of resonances, ascribable to the cis products. The $\mathrm{D}_{2} \mathrm{O}$ solubility values of $\mathbf{2 a - e}$ were previously reported [20], ranging in between $4.3 \times 10^{-4}(\mathbf{2 e})$ and $1.4 \times 10^{-2}(\mathbf{2 c})$ molar.

The vinyliminium complexes $\mathbf{2 a - e}$ were assessed for their cytotoxic activity against the human lung A549 and human pancreatic BxPC-3 cancer cell lines following $72 \mathrm{~h}$ incubation. The results are shown in Table 1 , together with previously reported IC $_{50}$ values concerning A2780 and A2780cisR cell lines [20]. Thus, complexes $\mathbf{2 b}$-e are substantially inactive against the newly investigated cell lines, whereas 2 a displays a significant cytotoxicity, with the $\mathrm{IC}_{50}$ obtained on the BxPC-3 line not so far from that of the reference drug cisplatin under the same conditions.

As explained in the Introduction, the activity of 2a-e may be imputable, at least in part, to redox processes associated to either a slow degradation of the complexes or their monoelectron reduction, the latter in some cases affording monoiron derivatives as organometallic products. In this regard, during an experiment aimed to test the stability of 2a in dimethylsulfoxide at $37^{\circ} \mathrm{C}$, we serendipitously discovered a clean conversion into the monoiron species $\mathbf{3 a}$ and cyclopentadiene (Scheme 2, path b). Complex 3a, which is almost insoluble in water, was identified based on a comparison of IR and ${ }^{1} \mathrm{H}$ NMR data with those available in the literature [27]. The IR spectrum, in dichloromethane solution, exhibits three characteristic bands due to the carbonyl ligand $\left(1919 \mathrm{~cm}^{-1}\right)$, the acyl group $\left(1612 \mathrm{~cm}^{-1}\right)$ and the aminoalkylidene moiety $\left(1571 \mathrm{~cm}^{-1}\right)$. The ${ }^{1} \mathrm{H}$ NMR spectrum (in the DMSO- $\mathrm{d}_{6}$ reaction medium; Figure $\mathrm{S} 4$ ) displays a single set of resonances ascribable to the E-configuration of the nitrogen substituents, with the alkenic $\mathrm{CH}$ proton resonating at $6.78 \mathrm{ppm}$. With reference to the biological action, although the conversion of $2 \mathbf{a}$ into $3 \mathbf{a}$ does not occur in water, it cannot be ruled out that the fragmentation of complexes of type 2 leading to 3 takes place in a physiological environment to some extent not exclusively through a redox mechanism (see Introduction) [20,38].

In order to outline a possible correlation between the activity of $2 \mathbf{a}$ and that of $3 \mathbf{a}$, we investigated the influence of time on the $\mathrm{IC}_{50}$ values on $\mathrm{A} 2780$ and $\mathrm{A} 2780$ cisR cells. The ratio between the $\mathrm{IC}_{50}$ values after 24 and $72 \mathrm{~h}$ of incubation, respectively, are 11 (A2780) and 21 (A2780cisR) for 2a and 2.3 (A2780) and 3.3 (A2780cisR) for 3a. This set of data highlights that the action of the diiron $\mathbf{2} \mathbf{a}$ is much slower than that of the monoiron $3 \mathbf{a}$ which is, however, less cytotoxic; it may be concluded that $\mathbf{2} \mathbf{a}$ is better internalized than $\mathbf{3 a}$ inside cells, and the kinetic of its antiproliferative activity is correlated to fragmentation routes (including that leading to $3 \mathbf{a}$ ).

Relevant to the cytotoxicity trials, the stability of $4 \mathrm{a}-\mathrm{c}$ was monitored at variable times in DMSO- $\mathrm{d}_{6} / \mathrm{D}_{2} \mathrm{O}$ mixtures, maintained at $37^{\circ} \mathrm{C}$ (see Experimental and Table 2 for details). According to ${ }^{1} \mathrm{H}$ NMR spectroscopy, the degradation rate of the complexes follows the trend $\mathbf{4 a}<\mathbf{4 c}<\mathbf{4 b}$, however extensive degradation occurs after $72 \mathrm{~h}$ in all cases (Table 2). The same trend was observed in analogous DMSO- $\mathrm{d}_{6} /$ deuterated cell culture medium (DMEM-d) mixtures after $24 \mathrm{~h}$, albeit with a slower process concerning especially $4 \mathbf{c}$ and $\mathbf{4 b}$. The diiron complexes 4a-c exhibit a moderate antiproliferative activity after $72 \mathrm{~h}$ incubation against the A2780 cells (Table 1); it is noteworthy that such activity is similar to that detected for the same compounds on the cisplatin resistant A2780cisR cell line. On the other hand, the cationic vinyliminium complexes 2 are much less cytotoxic towards the A2780cisR cells with respect to the A2780 ones. Interestingly, the selenophenes $\mathbf{5 a - b}$ are significantly 
less cytotoxic than the corresponding precursors $4 \mathbf{a}-\mathbf{b}$ (Table 1); this fact outlines that the capability of the investigated di-organoiron complexes to kill cancer cells may be mainly ascribable to the interference with the cell redox balance promoted by the iron centers, with a possible secondary contribution offered by the bridging organic moiety. In addition, carbon monoxide might play some adjuvant role, and investigations are in due course to give insight into this feature. It should be mentioned that a range of transition metal carbonyl complexes have been widely studied for the therapeutic properties associated to the controlled release of the carbonyl ligand(s) [39].

Table 1. $\mathrm{IC}_{50}$ values $(\mu \mathrm{M})$ determined for iron complexes and cisplatin on cell lines after $72 \mathrm{~h}$ exposure, unless otherwise specified. Values are given as the mean \pm SD. Italic: previously reported data from ref. [20]. ${ }^{*}$ Exposure time: $24 \mathrm{~h}$.

\begin{tabular}{ccccc}
\hline Comp. & A2780 & A2780cisR & A549 & BxPC-3 \\
\hline $\mathbf{2 a}$ & $0.50 \pm 0.06$ & $1.2 \pm 0.2$ & $43 \pm 4$ & $11.5 \pm 1.4$ \\
$\mathbf{2 a}$ & $5.3 \pm 1.2^{(*)}$ & $25 \pm 2^{(*)}$ & & \\
$\mathbf{2 b}$ & $0.90 \pm 0.06$ & $4.0 \pm 0.3$ & $>100$ & $>100$ \\
$\mathbf{2 c}$ & $35 \pm 3$ & $86 \pm 7$ & $>100$ & $>100$ \\
$\mathbf{2 d}$ & $2.9 \pm 0.2$ & $9.3 \pm 0.7$ & $>100$ & $>100$ \\
$\mathbf{2} \mathbf{e}$ & $1.8 \pm 0.2$ & $7.5 \pm 0.3$ & $>100$ & \\
$\mathbf{3 a}$ & $16 \pm 2$ & $26 \pm 3$ & & \\
$\mathbf{3 a}$ & $37 \pm 2^{(*)}$ & $86 \pm 4^{(*)}$ & & \\
$\mathbf{4 a}$ & $25.9 \pm 1.6$ & $29 \pm 3$ & & \\
$\mathbf{4 b}$ & $37 \pm 3$ & $42 \pm 6$ & & \\
$\mathbf{4 c}$ & $39 \pm 2$ & $50 \pm 6$ & & \\
$\mathbf{5 a}$ & $64 \pm 4$ & $>100$ & & \\
$\mathbf{5 b}$ & $>100$ & $>100$ & & \\
cisplatin & $19.0 \pm 1.1^{(*)}$ & $71 \pm 3^{(*)}$ & & \\
cisplatin & $0.40 \pm 0.07$ & $26 \pm 3$ & $9.5 \pm 0.6$ & \\
\hline
\end{tabular}

\section{Conclusions}

The search for new transition metal anticancer drugs, overcoming the limitations associated to the administration of platinum chemotherapics, is an intensively explored field of research, and, in this regard, iron is a convenient choice as a metal element essentially due to its limited intrinsic toxicity. Various iron compounds have been investigated for their anticancer potential, however studies on diiron complexes are still in their infancy, despite several advantages provided by the presence of two cooperating metal centers. Following our recent description of the promising cytotoxic activity of cationic diiron complexes with a bridging vinyliminium ligand, here we report additional studies on a selection of such category of complexes. One compound of the series, containing a phenyl group on the $\mathrm{C}_{3}$ chain, emerged as an effective cytotoxic agent against a panel of cancer cell lines. Since the mode of action seems ascribable, inter alia, to a slow fragmentation occurring in cells and affording a monoiron vinyl-aminoalkylidene derivative, we monitored the antiproliferative activities of the diiron phenyl precursor and of its monoiron counterpart at different times of incubation. The results support the hypothesis of the fragmentation reaction as one of the possible mechanisms of anticancer action. Then, analyses on neutral diiron complexes containing a selenophene-decorated ligand evidence a scarce influence of the organic moiety on the cytotoxicity, which is presumably best correlated to the redox activity of the iron centers and, eventually, to $\mathrm{CO}$ release. In summary, diiron organometallic complexes constitute an arsenal of robust compounds with ideal properties for a drug candidate (e.g., easy availability and straightforward synthesis, appreciable water solubility, water stability and amphiphilicity), and the wide opportunity for structural variability offered by the diiron core encourages further studies in the direction to find out optimal combinations of ligands and substituents for the development of potential pharmaceuticals deserving more advanced biological evaluation. 


\section{Experimental}

\subsection{Materials and Methods}

Solvents and organic reactants were purchased from Merck or TCI Europe. Compounds 1a [40], 2b,e [20,36], 3a [27], 4a-c [29] and 5a-b [29] were synthesized according to the respective literature procedures; once obtained, all the products were stored in air. Chromatography separations were carried out on columns of deactivated alumina (Merck, $4 \% w / w$ water), unless otherwise specified. Infrared spectra of solutions were recorded on a Perkin Elmer Spectrum 100 FT-IR spectrometer with a $\mathrm{CaF}_{2}$ liquid transmission cell (2300-1500 $\mathrm{cm}^{-1}$ range) and processed with Spectragryph software [41]. NMR spectra were recorded on a Bruker Avance II DRX400 instrument equipped with a BBFO broadband probe. Chemical shifts (expressed in parts per million) are referenced to the residual solvent peaks $\left({ }^{1} \mathrm{H}\right)$ [42]. NMR signals due to a second isomeric form (where it has been possible to detect them) are italicized. Elemental analyses were performed on a Vario MICRO cube instrument (Elementar).

\subsection{Synthesis of $\left[\mathrm{Fe}_{2} \mathrm{Cp}_{2}(\mathrm{CO})(\mu-\mathrm{CO})\left\{\mu-\eta^{1}: \eta^{3}-\mathrm{C}^{3}\left(\mathrm{R}^{\prime}\right) \mathrm{C}^{2}\left(\mathrm{R}^{\prime \prime}\right) \mathrm{C}^{1} \mathrm{NMe}(\mathrm{R})\right\}\right] \mathrm{CF}_{3} \mathrm{SO}_{3},(2 a, c, d)$}

General procedure: A red solution of $\mathbf{1 a - b}$ (ca. $0.15 \mathrm{mmol}$ ) and $\mathrm{Me}_{3} \mathrm{NO}$ (ca. $0.30 \mathrm{mmol}$ ) in $\mathrm{MeOH}(5 \mathrm{~mL})$ was treated with the appropriate alkyne (ca. $0.45 \mathrm{mmol})$, in an open system allowing the release of gaseous products $\left(\mathrm{Me}_{3} \mathrm{~N}\right.$ and $\left.\mathrm{CO}_{2}\right)$. The mixture was heated at $45^{\circ} \mathrm{C}$ for ca. $4 \mathrm{~h}$. Conversion was checked by IR spectroscopy and volatiles were removed under vacuum. The residue was dissolved in $\mathrm{CH}_{2} \mathrm{Cl}_{2}$ and moved on top of an alumina column (neutral, Brockmann activity I; h 6, d $2.3 \mathrm{~cm}$ ). Impurities were eluted with $\mathrm{CH}_{2} \mathrm{Cl}_{2}$ and THF, then a band was collected using $\mathrm{MeCN}$. The eluate was dried under vacuum and the resulting solid was triturated in $\mathrm{Et}_{2} \mathrm{O}$. The suspension was filtered; the solid was washed with $\mathrm{Et}_{2} \mathrm{O}$ and dried under vacuum.

$\left[\mathrm{Fe}_{2} \mathrm{Cp}_{2}(\mathrm{CO})(\mu-\mathrm{CO})\left\{\mu-\eta^{1}: \eta^{3}-\mathrm{C}^{3}(\mathrm{Ph}) \mathrm{C}^{2}(\mathrm{H}) \mathrm{C}^{1} \mathrm{NMe}(\mathrm{Xyl})\right\}\right] \mathrm{CF}_{3} \mathrm{SO}_{3}(2 \mathrm{a})[20,37]$. From 1a and phenylacetylene. Brown solid, yield $70 \%$. Anal. Calcd. for $\mathrm{C}_{31} \mathrm{H}_{28} \mathrm{Fe}_{2} \mathrm{~F}_{3} \mathrm{NO}_{5} \mathrm{~S}: \mathrm{C}$, $53.55 ; \mathrm{H}, 4.06 ; \mathrm{N}, 2.01$. Found: $\mathrm{C}, 53.42 ; \mathrm{H}, 4.13 ; \mathrm{N}, 1.94$. IR $\left(\mathrm{CH}_{2} \mathrm{Cl}_{2}\right): \widetilde{v} / \mathrm{cm}^{-1}=2000 \mathrm{vs}$ (CO), $1819 \mathrm{~s}(\mu-\mathrm{CO}), 1628 \mathrm{~m}\left(\mathrm{C}^{2} \mathrm{C}^{1} \mathrm{~N}\right) .{ }^{1} \mathrm{H}$ NMR $\left(\right.$ acetone- $\left.\mathrm{d}_{6}\right): \delta / \mathrm{ppm}=7.90\left(\mathrm{~d},{ }^{3} J_{\mathrm{HH}} \approx 7.4\right.$ $\mathrm{Hz}), 7.63-7.43(\mathrm{~m}, 5 \mathrm{H}, \mathrm{Ph}) ; 7.42-7.34(\mathrm{~m}), 7.25(\mathrm{t}), 7.17(\mathrm{~d}), 7.08(\mathrm{~d})\left({ }^{3} \mathrm{~J}_{\mathrm{HH}} \approx 7.5 \mathrm{~Hz}, 3 \mathrm{H}\right.$, $\left.\mathrm{C}_{6} \underline{\mathrm{H}}_{3} \mathrm{Me}_{2}\right) ; 5.67,5.33$ (s, $\left.5 \mathrm{H}, \mathrm{Cp}\right) ; 5.38,5.07$ (s, $\left.5 \mathrm{H}, \mathrm{Cp}\right) ; 5.13,4.28\left(\mathrm{~s}, 1 \mathrm{H}, \mathrm{C}^{2} \mathrm{H}\right) ; 4.42,3.74$ (s, $3 \mathrm{H}, \mathrm{NMe}) ; 2.60,2.33,2.08,1.88$ (s, $6 \mathrm{H}, \mathrm{C}_{6} \mathrm{H}_{3} \mathrm{Me}_{2}$ ). Cis-E/cis-Z ratio ca. 2:1.

$\left[\mathrm{Fe}_{2} \mathrm{Cp}_{2}(\mathrm{CO})(\mu-\mathrm{CO})\left\{\mu-\eta^{1}: \eta^{3}-\mathrm{C}^{3}(\mathrm{Me}) \mathrm{C}^{2}(\mathrm{H}) \mathrm{C}^{1} \mathrm{NMe}_{2}\right\}\right] \mathrm{CF}_{3} \mathrm{SO}_{3}(2 \mathrm{c})$ [20,23]. From $\mathbf{1 b}$ and propyne (THF solution ca. $1 \mathrm{~mol} / \mathrm{L}$ ). Brown solid, yield $90 \%$. Anal. Calcd. for $\mathrm{C}_{19} \mathrm{H}_{20} \mathrm{~F}_{3} \mathrm{Fe}_{2} \mathrm{NO}_{5} \mathrm{~S}: \mathrm{C}, 42.02 ; \mathrm{H}, 3.71 ; \mathrm{N}, 2.58 ; \mathrm{S}, 5.90$. Found: $\mathrm{C}, 42.11 ; \mathrm{H}, 3.61 ; \mathrm{N}, 2.68$; $\mathrm{S}, 5.80$. IR $\left(\mathrm{CH}_{2} \mathrm{Cl}_{2}\right): \tilde{v} / \mathrm{cm}^{-1}=1990 \mathrm{vs}(\mathrm{CO}), 1806 \mathrm{~s}(\mu-\mathrm{CO}), 1685 \mathrm{~m}\left(\mathrm{C}^{2} \mathrm{C}^{1} \mathrm{~N}\right) .{ }^{1} \mathrm{H} \mathrm{NMR}$ (acetone- $\left.\mathrm{d}_{6}\right): \delta / \mathrm{ppm}=5.50(\mathrm{~s}, 5 \mathrm{H}, \mathrm{Cp}) ; 5.18(\mathrm{~s}, 5 \mathrm{H}, \mathrm{Cp}) ; 4.59\left(\mathrm{~s}, 1 \mathrm{H}, \mathrm{C}^{2} \mathrm{H}\right) ; 3.95,3.94(\mathrm{~s}, 6$ $\left.\mathrm{H}, \mathrm{NMe}+\mathrm{C}^{3} \mathrm{Me}\right), 3.33(\mathrm{~s}, 3 \mathrm{H}, \mathrm{NMe})$. Cis isomer.

$\left[\mathrm{Fe}_{2} \mathrm{Cp}_{2}(\mathrm{CO})(\mu-\mathrm{CO})\left\{\mu-\eta^{1}: \eta^{3}-\mathrm{C}^{3}\right.\right.$ (2-naphthyl) $\left.\left.\mathrm{C}^{2}(\mathrm{H}) \mathrm{C}^{1} \mathrm{NMe}_{2}\right\}\right] \mathrm{CF}_{3} \mathrm{SO}_{3}(2 \mathrm{~d})$ [20]. From $\mathbf{1 b}$ and 1-ethynylnaphthalene. Dark-green solid, yield $88 \%$. Anal. Calcd. for $\mathrm{C}_{28} \mathrm{H}_{24} \mathrm{~F}_{3} \mathrm{Fe}_{2}$ $\mathrm{NO}_{5} \mathrm{~S}: \mathrm{C}, 51.32 ; \mathrm{H}, 3.69 ; \mathrm{N}, 2.14 ; \mathrm{S}, 4.89$. Found: $\mathrm{C}, 51.20 ; \mathrm{H}, 3.77 ; \mathrm{N}, 2.03 ; \mathrm{S}, 4.96$. IR $\left(\mathrm{CH}_{2} \mathrm{Cl}_{2}\right): \tilde{v} / \mathrm{cm}^{-1}=1988 \mathrm{vs}(\mathrm{CO}), 1809 \mathrm{~s}(\mu-\mathrm{CO}), 1687 \mathrm{~m}\left(\mathrm{C}^{2} \mathrm{C}^{1} \mathrm{~N}\right) .{ }^{1} \mathrm{H}$ NMR (acetone- $\left.\mathrm{d}_{6}\right):$ $\delta / \mathrm{ppm}=8.22(\mathrm{~d}, \mathrm{~J}=7.2 \mathrm{~Hz}), 8.07(\mathrm{~d}, \mathrm{~J}=7.7 \mathrm{~Hz}), 8.00(\mathrm{t}, \mathrm{J}=7.0 \mathrm{~Hz}), 7.74(\mathrm{t}, \mathrm{J}=7.7 \mathrm{~Hz})$, 7.65-7.53 (m) $\left(7 \mathrm{H}, \mathrm{C}_{9} \mathrm{H}_{7}\right) ; 5.54(\mathrm{~s}, 5 \mathrm{H}, \mathrm{Cp}), 5.10(\mathrm{~s}, 5 \mathrm{H}, \mathrm{Cp}), 4.79\left(\mathrm{~s}, 1 \mathrm{H}, \mathrm{C}^{2} \mathrm{H}\right) ; 4.08,3.51(\mathrm{~s}$, $\left.6 \mathrm{H}, \mathrm{NMe}_{2}\right)$. Cis isomer.

\subsection{Stability in DMSO/Water Mixtures}

\subsubsection{Formation of $\left[\mathrm{FeCp}(\mathrm{CO})\left\{\mathrm{C}^{1}(\mathrm{NMeXyl}) \mathrm{C}^{2} \mathrm{HC}^{3}(\mathrm{Ph}) \mathrm{C}(\mathrm{O})\right\}\right]$, 3a, in $\mathrm{DMSO}^{-\mathrm{d}_{6}}$}

Under a $\mathrm{N}_{2}$ atmosphere, compound $\mathbf{2 a}$ (ca. $4 \mathrm{mg}$ ) was dissolved in DMSO- $\mathrm{d}_{6}(0.9 \mathrm{~mL})$. The orange-brown solution was analysed by ${ }^{1} \mathrm{H}$ NMR then heated at $37^{\circ} \mathrm{C}$ for $72 \mathrm{~h}$. Next, the mixture was filtered over celite and ${ }^{1} \mathrm{H}$ NMR spectrum was recorded. ${ }^{1} \mathrm{H}$ NMR analysis revealed a quantitative conversion into a mixture of $\mathbf{3 a}$ and cyclopentadiene (1:1 molar ratio). 2a. ${ }^{1} \mathrm{H}$ NMR (DMSO- $\mathrm{d}_{6}$ ): $\delta / \mathrm{ppm}=7.82(\mathrm{~d}), 7.58(\mathrm{t}), 7.32(\mathrm{~d}), 7.22(\mathrm{t}), 7.16(\mathrm{~d}), 7.05(\mathrm{~d})$ 
$\left({ }^{3} \mathrm{~J}_{\mathrm{HH}} \approx 7.6 \mathrm{~Hz}, 3 \mathrm{H}, \mathrm{C}_{6} \underline{\mathrm{H}}_{3} \mathrm{Me}_{2}\right) ; 7.50-7.43,7.40-7.34(\mathrm{~m}, 5 \mathrm{H}, \mathrm{Ph}) ; 5.61,5.33,5.28,4.96(\mathrm{~s}$, $10 \mathrm{H}, \mathrm{Cp}) ; 5.11,4.10\left(\mathrm{~s}, 1 \mathrm{H}, \mathrm{C}^{2} \mathrm{H}\right) ; 4.25,3.57(\mathrm{~s}, 3 \mathrm{H}, \mathrm{NMe}) ; 2.46^{*}, 2.22,1.97,1.77$ (s, 6H, $\left.\mathrm{C}_{6} \mathrm{H}_{3} \underline{\mathrm{Me}}_{2}\right)$. ${ }^{*}$ Over DMSO-d 6 peak. Cis-E/cis-Z ratio ca. 7:1. 3a. ${ }^{1} \mathrm{H}$ NMR (DMSO-d $\mathrm{d}_{6}$ ): $\delta / \mathrm{ppm}=7.40-7.13\left(\mathrm{~m}, 8 \mathrm{H}, \mathrm{C}_{6} \mathrm{H}_{3} \mathrm{Me}_{2}+\mathrm{Ph}\right) ; 6.78\left(\mathrm{~s}, 1 \mathrm{H}, \mathrm{C}^{2} \mathrm{H}\right) ; 4.70(\mathrm{~s}, 5 \mathrm{H} \mathrm{Cp}) ; 3.82(\mathrm{~s}, 3 \mathrm{H}$, $\mathrm{NMe}) ; 2.22,2.07\left(\mathrm{~s}, 6 \mathrm{H}, \mathrm{C}_{6} \mathrm{H}_{3} \mathrm{Me}_{2}\right) . \mathrm{CpH} .{ }^{1} \mathrm{H}$ NMR $\left(\mathrm{DMSO}_{-} \mathrm{d}_{6}\right): \delta / \mathrm{ppm}=6.56(\mathrm{~m}, 2 \mathrm{H})$, $6.47(\mathrm{~m}, 2 \mathrm{H}), 2.95(\mathrm{~m}, 2 \mathrm{H})$. The mixture was extracted with hexane $(2 \times 10 \mathrm{~mL})$, then the volatiles were removed under vacuum. Subsequent IR spectrum evidenced the presence of 3a as unique carbonyl species. IR $\left(\mathrm{CH}_{2} \mathrm{Cl}_{2}\right): \tilde{v} / \mathrm{cm}^{-1}=1919 \mathrm{vs}(\mathrm{CO}), 1612 \mathrm{~m}\left(\mathrm{CO}_{\text {acyl }}\right)$, $1571 \mathrm{~m}\left(\mathrm{C}^{1} \mathrm{~N}\right)$.

\subsubsection{Stability in DMSO- $\mathrm{d}_{6} / \mathrm{D}_{2} \mathrm{O}$}

The selected diiron complex (ca. $8 \mathrm{mg}$ ) was dissolved in $5 \mathrm{~mL}$ of a mixture of DMSO- $\mathrm{d}_{6}$ and $\mathrm{D}_{2} \mathrm{O}(4: 1 \mathrm{v} / \mathrm{v})$, and the resulting solution was thermostated at $37^{\circ} \mathrm{C}$. An aliquot of the solution was withdrawn after 7, 24, 48 and $72 \mathrm{~h}$, filtrated through a short celite pad and analyzed by ${ }^{1} \mathrm{H}$ NMR (Table 2).

\subsubsection{Stability in DMSO- $\mathrm{d}_{6} /$ DMEM-d Cell Culture Medium}

The selected diiron complex (ca. $8 \mathrm{mg}$ ) was dissolved in $5 \mathrm{~mL}$ of a mixture of DMSO- $\mathrm{d}_{6}$ and DMEM-d cell culture medium ( $4: 1 v / v)$, and the resulting solution was thermostated at $37^{\circ} \mathrm{C}$. An aliquot of the solution was withdrawn after 6,24 and $72 \mathrm{~h}$, filtrated through a short celite pad and analyzed by ${ }^{1} \mathrm{H}$ NMR (Table 2).

Table 2. Fraction (\%) of diiron complex (measured as released cyclopentadiene, two $\mathrm{CpH}$ units being released per molecule [19]) degraded in aqueous solutions stored at $37^{\circ} \mathrm{C}$ after variable times (hours).

\begin{tabular}{|c|c|c|c|c|c|c|c|}
\hline \multirow{2}{*}{ Comp. } & \multicolumn{4}{|c|}{ DMSO- $\mathrm{d}_{6} / \mathrm{D}_{2} \mathrm{O}$} & \multicolumn{3}{|c|}{ DMSO-d 6 /DMEM-d } \\
\hline & $6 \mathrm{~h}$ & $24 \mathrm{~h}$ & $48 \mathrm{~h}$ & $72 \mathrm{~h}$ & $6 \mathrm{~h}$ & $24 \mathrm{~h}$ & $72 \mathrm{~h}$ \\
\hline $4 a$ & 3 & 13 & 27 & 70 & 5 & 9 & 100 \\
\hline $4 b$ & 25 & 71 & 100 & 100 & 13 & 49 & 100 \\
\hline $4 c$ & 17 & 60 & 88 & 100 & 9 & 20 & 100 \\
\hline
\end{tabular}

\subsection{In Vitro Cytotoxicity Investigation}

\subsubsection{Cell Lines}

In vitro cytotoxicity investigations were carried out by using human ovarian carcinoma cisplatin-sensitive A2780 (ECACC93112519), human ovarian carcinoma cisplatinresistant A2780cisR (ECACC 93112517), human lung carcinoma A549 (CCL-185) and human pancreas adenocarcinoma BxPC-3 cell lines (CRL-1687). A2780 and A2780cisR were purchased from the European Collection of Authenticated Cell Cultures (ECACC), and A549 and BxPC-3 cell lines from the American Type Culture Collection (ATCC).

The cell lines were propagated as indicated by the supplier in RPMI 1640 (MerckA2780, A2780cisR and BxPC-3) and Ham's F12 medium (Merck-A549) containing 2 mM of L-glutamine (Merck), $1 \%$ of penicillin/streptomycin solution (Merck-10,000 $\mathrm{U} \mathrm{ml}^{-1}$ : $10 \mathrm{mg} \mathrm{ml}^{-1}$ ), 10\% of fetal bovine serum (Merck-FBS) and antimycotic. The acquired resistance of A2780cisR cells was maintained by routine supplementation of media with $1 \mu \mathrm{M}$ of cisplatin and the BxPC-3 medium was also supplemented with $1 \%$ of sodium pyruvate (Merck). The cells were maintained under standard tissue culture conditions of $37^{\circ} \mathrm{C}$ and $5 \%$ atmosphere of $\mathrm{CO}_{2}$.

\subsubsection{Cytotoxicity Assay}

Prior to incubation with the selected complex for $72 \mathrm{~h}, \mathrm{~A} 2780, \mathrm{~A} 2780$ cisR, BxPC-3 and A549 cells were seeded in 96 wells tissue culture polystyrene plates at a concentration of $3 \times 10^{3}, 6 \times 10^{3}, 7 \times 10^{3}$ and $3 \times 10^{3}$ cells per well, respectively, and allowed to proliferate for $24 \mathrm{~h}$ at $37^{\circ} \mathrm{C}$ in a $5 \%$ atmosphere of $\mathrm{CO}_{2}$. For the assay at $24 \mathrm{~h}, \mathrm{~A} 2780$ and A2780cisR cells were seeded at a concentration of $1 \times 10^{4}$ and $1.5 \times 10^{4}$ cells per well, respectively. Stock solutions of compounds were prepared in DMSO and were sequentially diluted in 
medium (final DMSO concentration of $0.5 \%$ ) to achieve the final desired concentration $(0-100 \mu \mathrm{M})$. Cells incubated with cisplatin $(0-100 \mu \mathrm{M})$ were used as positive control. Cells were treated with the different concentration of compounds for 24 or $72 \mathrm{~h}$ at $37^{\circ} \mathrm{C}$ in a $5 \%$ atmosphere of $\mathrm{CO}_{2}$. At the end of the incubation time, cell viability was assessed by means of WST-1 tetrazolium salt reagent (Roche). Briefly, cells were incubated for $4 \mathrm{~h}$ with WST-1 reagent diluted $1: 10$, at $37^{\circ} \mathrm{C}$ and $5 \% \mathrm{CO}_{2}$. Measurements of formazan dye absorbance, which directly correlates with the number of viable cells, were carried out with a microplate reader (Biorad, Milan) at $450 \mathrm{~nm}$, using $655 \mathrm{~nm}$ as reference wavelength. The $50 \%$ inhibitory concentration of tested compound $\left(\mathrm{IC}_{50}\right)$ refers to concentration at which $50 \%$ of cell death is observed with respect to the control. All the in vitro biological tests were performed in triplicate. Concentration effect curves were generated by nonlinear regression curves (GraphPad Prism) and the data are reported as mean \pm standard deviation.

Supplementary Materials: The following are available online at https:/ / www.mdpi.com/article/10 .3390/app11104351/s1, Figures S1-S4: NMR spectra of complexes.

Author Contributions: Conceptualization, F.M. and F.C.; methodology, L.B. and S.B.; investigation, L.B., S.B. and G.P. (Giacomo Provinciali); data curation, L.B., S.B., F.C. and F.M.; writing-original draft preparation, F.M.; writing-review and editing, L.B., S.B., G.P. (Guido Pampaloni), F.C. and F.M.; supervision, F.C. and F.M.; funding acquisition, L.B., S.B., G.P. (Guido Pampaloni), F.C. and F.M. All authors have read and agreed to the published version of the manuscript.

Funding: This research was funded by University of Pisa, Fondi di Ateneo 2020.

Institutional Review Board Statement: Not applicable.

Informed Consent Statement: Not applicable.

Data Availability Statement: Data is contained within the article or supplementary material.

Conflicts of Interest: The authors declare no conflict of interest.

\section{References}

1. Murray, B.S.; Dyson, P.J. Recent progress in the development of organometallics for the treatment of cancer. Curr. Opinion Chem. Biol. 2020, 56, 28-34. [CrossRef]

2. Štarha, P.; Trávníček, Z. Non-platinum complexes containing releasable biologically active ligands. Coord. Chem. Rev. 2019, 395, 130-145. [CrossRef]

3. Bratsos, I.; Gianferrara, T.; Alessio, E.; Hartinger, C.G.; Jakupec, M.A.; Keppler, B.K. Ruthenium and Other Non-Platinum Anticancer Compounds. In Bioinorganic Medicinal Chemistry; Alessio, E., Ed.; Wiley-VCH: Weinheim, Germany, $2011 ;$ pp. 151-174.

4. Boros, E.; Dyson, P.J.; Gasser, G. Classification of Metal-Based Drugs according to Their Mechanisms of Action. Chem 2020, 6, 41-60. [CrossRef] [PubMed]

5. Anthony, E.J.; Bolitho, E.M.; Bridgewater, H.E.; Carter, O.W.L.; Donnelly, J.M.; Imberti, C.; Lant, E.C.; Lermyte, F.; Needham, R.J.; Palau, M.; et al. Metallodrugs are unique: Opportunities and challenges of discovery and development. Chem. Sci. 2020, 11, 12888-12917. [CrossRef]

6. Oun, R.; Moussa, Y.E.; Wheate, N.J. The side effects of platinum-based chemotherapy drugs: A review for chemists. Dalton Trans. 2018, 47, 6645-6653. [CrossRef] [PubMed]

7. Siddik, Z.H. Cisplatin: Mode of cytotoxic action and molecular basis of resistance. Oncogene 2003, 22, 7265-7279. [CrossRef] [PubMed]

8. Kaim, W.; Schwederski, B.; Klein, A. Bioinorganic Chemistry: Inorganic Elements in the Chemistry of Life, 2nd ed.; Wiley: Hoboken, NJ, USA, 2013.

9. Zoroddu, M.A.; Aaseth, J.; Crisponi, G.; Medici, S.; Peana, M.; Nurchi, V.M. The essential metals for humans: A brief overview. J. Inorg. Biochem. 2019, 195, 120-129. [CrossRef]

10. Patra, M.; Gasser, G. The medicinal chemistry of ferrocene and its derivatives. Nat. Chem. Rev. 2017, 1. [CrossRef]

11. Sansook, S.; Hassell-Hart, S.; Ocasio, C.; Spencer, J. Ferrocenes in medicinal chemistry; a personal perspective. J. Organomet. Chem. 2020, 905, 121017. [CrossRef]

12. Pilon, A.; Brás, A.R.; Côrte-Real, L.; Avecilla, F.; Costa, P.J.; Preto, A.; Garcia, M.H.; Valente, A. A New Family of Iron(II)Cyclopentadienyl Compounds Shows Strong Activity against Colorectal and Triple Negative Breast Cancer Cells. Molecules 2020, 25, 1592. [CrossRef]

13. Buriez, O.; Heldt, J.M.; Labb, E.; Vessières, A.; Jaouen, G.; Amatore, C. Reactivity and Antiproliferative Activity of FerrocenylTamoxifen Adducts with Cyclodextrins against Hormone-Independent Breast-Cancer Cell Lines. Chem. Eur. J. 2008, 14, 8195-8203. [CrossRef] 
14. Vessières, A.; Wang, Y.; McGlinchey, M.J.; Jaouen, G. Multifaceted chemical behaviour of metallocene (M = Fe, Os) quinone methides. Their contribution to biology. Coord. Chem. Rev. 2021, 430, 213658. [CrossRef]

15. Marchetti, F. Constructing Organometallic Architectures from Aminoalkylidyne Diiron Complexes. Eur. J. Inorg. Chem. 2018, 3987-4003. [CrossRef]

16. Mazzoni, R.; Marchetti, F.; Cingolani, A.; Zanotti, V. Bond Forming Reactions Involving Isocyanides at Diiron Complexes. Inorganics 2019, 7, 25. [CrossRef]

17. Biancalana, L.; Ciancaleoni, G.; Zacchini, S.; Pampaloni, G.; Marchetti, F. Carbonyl-isocyanide mono-substitution in $\left[\mathrm{Fe}_{2} \mathrm{Cp}_{2}(\mathrm{CO})_{4}\right]$ : A re-visitation. Inorg. Chim. Acta 2020, 517, 120181. [CrossRef]

18. Agonigi, G.; Biancalana, L.; Lupo, M.G.; Montopoli, M.; Ferri, N.; Zacchini, S.; Binacchi, F.; Biver, T.; Campanella, B.; Pampaloni, G.; et al. Exploring the Anticancer Potential of Diiron Bis-cyclopentadienyl Complexes with Bridging Hydrocarbyl Ligands: Behavior in Aqueous Media and In Vitro Cytotoxicity. Organometallics 2020, 39, 645-657. [CrossRef]

19. Schoch, S.; Batchelor, L.K.; Funaioli, T.; Ciancaleoni, G.; Zacchini, S.; Braccini, S.; Chiellini, F.; Biver, T.; Pampaloni, G.; Dyson, P.J.; et al. Diiron Complexes with a Bridging Functionalized Allylidene Ligand: Synthesis, Structural Aspects, and Cytotoxicity. Organometallics 2020, 39, 361-373. [CrossRef]

20. Rocco, D.; Batchelor, L.K.; Agonigi, G.; Braccini, S.; Chiellini, F.; Schoch, S.; Biver, T.; Funaioli, T.; Zacchini, S.; Biancalana, L.; et al. Anticancer Potential of Diiron Vinyliminium Complexes. Chem. Eur. J. 2019, 25, 14801-14816. [CrossRef]

21. Agonigi, G.; Batchelor, L.K.; Ferretti, E.; Schoch, S.; Bortoluzzi, M.; Braccini, S.; Chiellini, F.; Biancalana, L.; Zacchini, S.; Pampaloni, G.; et al. Mono-, Di- and Tetra-iron Complexes with Selenium or Sulphur Functionalized Vinyliminium Ligands: Synthesis, Structural Characterization and Antiproliferative Activity. Molecules 2020, 25, 1656. [CrossRef] [PubMed]

22. Rocco, D.; Busto, N.; Pérez-Arnaiz, C.; Biancalana, L.; Zacchini, S.; Pampaloni, G.; Garcia, B.; Marchetti, F. Antiproliferative and bactericidal activity of diiron and monoiron cyclopentadienyl carbonyl complexes comprising a vinyl-aminoalkylidene unit. Appl. Organomet. Chem. 2020, 34, 5923. [CrossRef]

23. Ciancaleoni, G.; Zacchini, S.; Zanotti, V.; Marchetti, F. DFT Mechanistic Insights into the Alkyne Insertion Reaction Affording Diiron $\mu$-Vinyliminium Complexes and New Functionalization Pathways. Organometallics 2018, 37, 3718-3731. [CrossRef]

24. Wang, P.; Gong, Q.; Hu, J.; Li, X.; Zhang, X. Reactive Oxygen Species (ROS)-Responsive Prodrugs, Probes, and Theranostic Prodrugs: Applications in the ROS-Related Diseases. J. Med. Chem. 2021, 64, 298-325. [CrossRef] [PubMed]

25. Hwang, E.; Jung, H.S. Metal-organic complex-based chemodynamic therapy agents for cancer therapy. Chem. Commun. 2020, 56, 8332-8341. [CrossRef]

26. Marzenell, P.; Hagen, H.; Sellner, L.; Zenz, T.; Grinyte, R.; Pavlov, V.; Daum, S.; Mokhir, A. Aminoferrocene-Based Prodrugs and Their Effects on Human Normal and Cancer Cells as Well as Bacterial Cells. J. Med. Chem. 2013, 56, 6935-6944. [CrossRef]

27. Rocco, D.; Batchelor, L.K.; Ferretti, E.; Zacchini, S.; Pampaloni, G.; Dyson, P.J.; Marchetti, F. Piano Stool Aminoalkyli-deneFerracyclopentenone Complexes from Bimetallic Precursors: Synthesis and Cytotoxicity, Data. ChemPlusChem 2020, 85, 110-122. [CrossRef]

28. Busetto, L.; Marchetti, F.; Zacchini, S.; Zanotti, V. Unprecedented Zwitterionic Iminium-Chalcogenide Bridging Ligands in Diiron Complexes. Organometallics 2006, 25, 4808-4816. [CrossRef]

29. Provinciali, G.; Bortoluzzi, M.; Funaioli, T.; Zacchini, S.; Campanella, B.; Pampaloni, G.; Marchetti, F. Tetrasubstituted Selenophenes from the Stepwise Assembly of Molecular Fragments on a Diiron Frame and Final Cleavage of a Bridging Alkylidene. Inorg. Chem. 2020, 59, 17497-17508. [CrossRef] [PubMed]

30. Brayshaw, S.K.; Clarke, L.P.; Homanen, P.; Koentjoro, O.F.; Warren, J.E.; Raithby, P.R. Arene—Ruthenium(II) Complexes Containing Amino-Phosphine Ligands as Catalysts for Nitrile Hydration Reactions. Organometallics 2011, 30, 3955-3965. [CrossRef]

31. Gandin, V.; Khalkar, P.; Braude, J.; Fernandes, A.P. Organic selenium compounds as potential chemotherapeutic agents for improved cancer treatment. Free Radic. Biol. Med. 2018, 127, 80-97. [CrossRef]

32. Collery, C. Strategies for the development of selenium-based anticancer drugs. J. Trace Elem. Med. Biol. 2018, 50, 498-507. [CrossRef] [PubMed]

33. Fernandes, A.P.; Gandin, V. Selenium compounds as therapeutic agents in cancer. Biochim. Biophys. Acta 2015, 1850, 1642-1660. [CrossRef]

34. Tan, H.-W.; Mo, H.-J.; Lau, A.T.Y.; Xu, Y.-M. Selenium Species: Current Status and Potentials in Cancer Prevention and Therapy. Int. J. Mol. Sci. 2019, 20, 75. [CrossRef]

35. Tiekink, E.R.T. Therapeutic potential of selenium and tellurium compounds: Opportunities yet unrealized. Dalton Trans. 2012, 41, 6390-6395. [CrossRef]

36. Albano, V.G.; Busetto, L.; Marchetti, F.; Monari, M.; Zacchini, S.; Zanotti, V. Hydride addition at $\mu$-vinyliminium ligand obtained from disubstituted alkynes. J. Organomet. Chem. 2005, 690, 837-846. [CrossRef]

37. Albano, V.G.; Busetto, L.; Marchetti, F.; Monari, M.; Zacchini, S.; Zanotti, V. Diiron $\mu$-Vinyliminium Complexes from Acetylene Insertion into a Metal-Aminocarbyne Bond. Organometallics 2003, 22, 1326-1331. [CrossRef]

38. Agonigi, G.; Ciancaleoni, G.; Funaioli, T.; Zacchini, S.; Pineider, F.; Pinzino, C.; Pampaloni, G.; Zanotti, V.; Marchetti, F. Controlled Dissociation of Iron and Cyclopentadienyl from a Diiron Complex with a Bridging C3 Ligand Triggered by One-Electron Reduction. Inorg. Chem. 2018, 57, 15172-15186. [CrossRef] [PubMed]

39. Jiang, X.; Xiao, Z.; Zhong, W.; Liu, X. Brief survey of diiron and monoiron carbonyl complexes and their potentials as CO-releasing molecules (CORMs). Coord. Chem. Rev. 2021, 429, 213634. [CrossRef] 
40. Agonigi, G.; Bortoluzzi, M.; Marchetti, F.; Pampaloni, G.; Zacchini, S.; Zanotti, V. Regioselective Nucleophilic Additions to Diiron Carbonyl Complexes Containing a Bridging Aminocarbyne Ligand: A Synthetic, Crystallographic and DFT Study. Eur. J. Inorg. Chem. 2018, 2018, 960-971. [CrossRef]

41. Menges, F. "Spectragryph-Optical Spectroscopy Software”, Version 1.2.5, @ 2016-2017. Available online: http:/ /www.effemm2 .de/spectragryph (accessed on 20 April 2021).

42. Fulmer, G.R.; Miller, A.J.M.; Sherden, N.H.; Gottlieb, H.E.; Nudelman, A.; Stoltz, B.M.; Bercaw, J.E.; Goldberg, K.I. NMR Chemical Shifts of Trace Impurities: Common Laboratory Solvents, Organics, and Gases in Deuterated Solvents Relevant to the Organometallic Chemist. Organometallics 2010, 29, 2176-2179. [CrossRef] 